\title{
THE ECUADORIAN MOHO
}

\author{
EL MOHO EN ECUADOR
}

\author{
Sebastián Araujo ${ }^{1,2}$ \\ ${ }^{1}$ Centro de Investigación en Modelamiento Ambiental CIMA, Universidad Politécnica Salesiana, Dir. Av. 12 de Octubre N24-22 \\ y Wilson, Quito, Ecuador. \\ 2 Institut des Sciences de la Terre ISTERRE, Université de Grenoble, Dir. 1381, rue de la Piscine 38400 Saint-Martin d'Hères, \\ France. \\ Corresponding author: jaraujo@ups.edu.ec
}

Article received on September 18th, 2013. Approved after revision on November 30th, 2013.

\begin{abstract}
Three MOHO models are investigated in order to fix one previous to tomographic inversion. Gravimetric Chambat-Valette model, three dimensional velocity model and gravimetric satellite research were used in the Ecuador region. A final assembly of the best characteristics of three models is presented as a result.

Keywords: Mohorovicic discontinuity, tomographic inversion, subduction slab, Ecuador.

Resumen

Como requisito previo para la consecución de imágenes tomográficas se estudian tres modelos de MOHO. Para la región de Ecuador se analizan el modelo gravimétrico de Chambat-Valette, un modelo de velocidades de propagación de ondas sísmicas en tres dimensiones y un modelo de observaciones gravimétricas satelitales. Se presenta como resultado un modelo que junta las mejores características de estas tres investigaciones previas.
\end{abstract}

Palabras claves: discontinuidad de Mohorovicic, inversión tomográfica, slab de subducción, Ecuador.

Suggested citation: $\quad$ Araujo, S. 2013. The ecuadorian MOHO. La Granja. Vol. 18(2): 43-47. ISSN: 1390-3799.

\section{Introduction}

With the formal idea of making a correct image from subduction slab in Ecuador regions, a good knowledge of the MOHOrovicic discontinuity is required. The MOHOrovicic discontinuity, simply called $\mathrm{MOHO}$, is the boundary between crust and mantle. It was discovered looking at a refraction of seismic waves patterns. This refraction is due to the existence of clear changes in density structure of the Earth, hence a change in refraction index. Other physical parameters like seismic reflexion, electrical conductivity and gravity potential allow to define a geophysical MOHO like the boundary detected and confirmed through all theses geophysical techniques (Cook et al., 2010).

The physical behavior of this boundary is not well-known yet; the crust being like a brittle fracture elastic media (Scholz, 2002) and mantle like viscoelastic media (Machetel, 2008), MOHO must be waited to exhibit an intermediate solid-liquid phase. This idea, known as the metamorphic (or metasomatic) front hypothesis, posits that the $\mathrm{MOHO}$ 
is overprinted by a phase transformation (Eaton, 2006). Nevertheless, this explanation seems too simple because first it is necessary to recognize $\mathrm{MOHO}$ discontinuity can be produced by another more complex geophysical phenomena, at least: relict $\mathrm{MOHO}$ posits that oceanic $\mathrm{MOHO}$ is preserved during continental assembly; the magmatic underplaying hypothesis posits formation of a new $\mathrm{MOHO}$ by episodic emplacement of sill-like intrusive bodies; and the regional decollement hypothesis posits that the MOHO behaves as a structural detachment (Eaton, 2006).

One of the astonishing recently discovered characteristics of $\mathrm{MOHO}$ is the tremor generated in its region. This seismic phenomena is a low frequency signal that is not associated with fracture episodes directly, for this reason, a fluid flow model was proposed to explain this phenomena (Katsumata and Kamaya, 2003), although a shear slip movement of crust over mantle is a more plausible explanation today (Shelly et al., 2006).

Coming back to the Ecuadorian MOHO question, any direct experience was achieved to elucidate the problem. Despite this lack of information, three previous studies were found. A summary of the main characteristics are presented in chronological order.

\section{Materials and Methods}

\subsection{Gravimetry MOHO (Chambat, 1996)}

It comes from geopotential and topography data inversion with a 0.1 resolution degree. The model is global and a window over the study region was chosen.

For the oceanic crust $\mathrm{MOHO}$ reaches $15 \mathrm{~km}$ thickness and goes up to $20 \mathrm{~km}$ in Carnegie Ridge. North Andean block in the coastal region has $35 \mathrm{~km}$ with a decline of $30 \mathrm{~km}$ in the Borbon and Manabi basins. Two apparent anomalies are detected, one positive in Guayaquil Gulf due to the presence of sediments and another one positive in the El Progreso Basin. Thin junctions with $45 \mathrm{~km}$ depth border the Andean Cordillera where MOHO falls to 55$60 \mathrm{~km}$. The Amazonian Region yields over Guiana Shield with $40 \mathrm{~km}$ depth. Finally a serious anomaly was detected between the Central Ecuadorian Andes and Guiana Shield. All these mentioned features can be seen on Figure 1.

\subsection{GEMMA MOHO (Reguzzoni and Sampietro, 2012)}

This global MOHO model was origin in GOCE satellite measurements of gravity field. These data were inverted and interpolate until obtaining a 0.1 degree resolution grid of crust depth. Resulting models, called GEMMA MODELS, are free access in web page of Laboratorio di Geomatica at Milan Polytechnic: 〈geomatica.com.polimi.it〉.

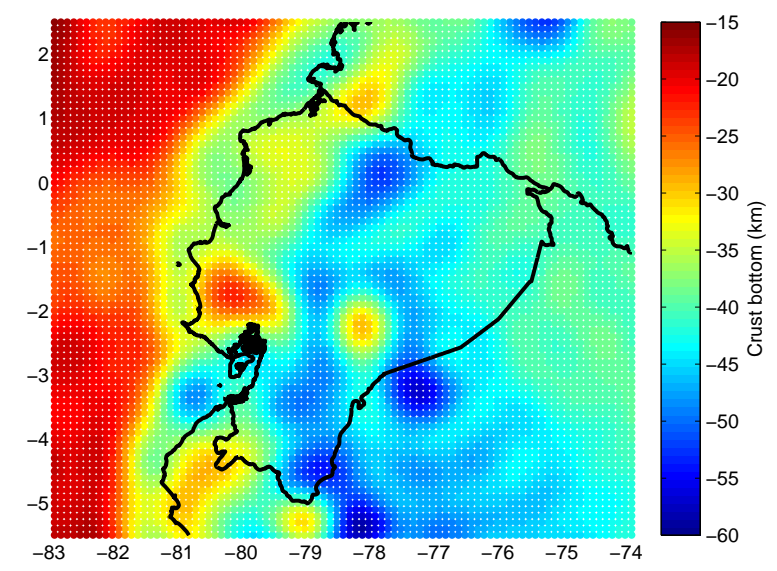

Figure 1. MOHO model from gravity 0.1 degree model. Principal problem for this model is the excessive oscillation in Andes.

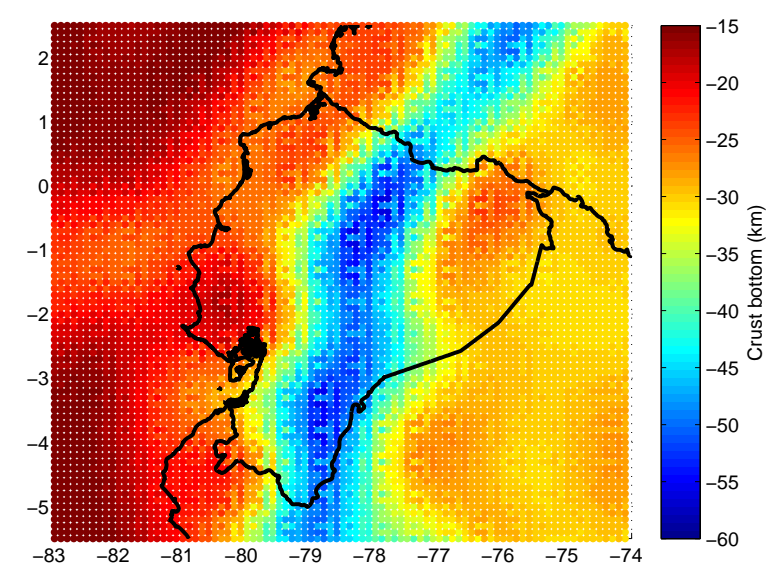

Figure 2. GEMMA model for $\mathrm{MOHO}$ in Ecuador. Main achievement of this model is reducing anomaly oscillations in inversion processes. MOHO depths for Coast and Amazonian Basins nevertheless seem to be overestimated.

LA GRANJA, Revista de Ciencias de la Vida, 18(2) 2013: 43-47.

(C) 2013, Universidad Politécnica Salesiana, Ecuador. 
In Figure 2 a window over Ecuador's region is presented. It shows $15 \mathrm{~km}$ depth for oceanic crust but a separation between Carnegie Ridge and North Andean Block is not clear because a continuity of 20 to $25 \mathrm{~km}$ depth. Anomalies on the Guayaquil Gulf and El Progreso Basin are signaled. Transitions to Western and Eastern Cordilleras extend from 32-45 $\mathrm{km}$ for crust thickness. Andean MOHO is situated at $60 \mathrm{~km}$ and finally the Guiana basin reaches $30 \mathrm{~km}$ depth.

In order to obtain Andes MOHO from the GOCE model, a data filtering parameter was taken where the deepest values were no more than $-32 \mathrm{~km}$.

\subsection{D-a priori seismic MOHO (Font et al., 2013)}

It is based on a compilation of anterior gravimetry researches specifically made for the Ecuadorian region and its first objective is not a $\mathrm{MOHO}$ representation, but rather, a three-dimensional velocity model for P seismic waves. Notwithstanding, is the most detailed summary for these days and it gives explicitly a description over each geodynamic area.

Beginning with the north of oceanic crust MOHO falls $5 \mathrm{~km}$ depth south of Colombia, it goes up to $19 \mathrm{~km}$ over Carnegie Ridge and back $14 \mathrm{~km}$ south of the ridge. Oceanic $\mathrm{MOHO}$ is defined here in a general sense like an abrupt velocity gradient from 7 to $7.8 \mathrm{~km} / \mathrm{s}$ in $1 \mathrm{~km}$.

Positioning of the continental crust for the coastal region: we found the North Andean block where $\mathrm{MOHO}$ has depths of 22 to $30 \mathrm{~km}$ and it is present in an interface of $7 \mathrm{~km} / \mathrm{s}$.

For the Andes, western and eastern cordilleras and inter-Andean region, 55-65 $\mathrm{km}$ of crust thickness and 7-8 km/s interface crust-mantle seem evident. Both cordilleras join plateaus with $30 \mathrm{~km}$ $\mathrm{MOHO}$ in depth in a 7-7.8 km/ structure.

And in the Amazon basin, Guiana Shield appears with a $30-35 \mathrm{~km}$ crust thickness and a $6.8 \mathrm{~km} / \mathrm{s}$ change in P-waves velocity between crust and mantle. With all these formations in mind, a model of $\mathrm{MOHO}$ was achieved taken parameters for 3DVM filtering: $P$ wave maximum velocity $8 \mathrm{~km} / \mathrm{s}, P$ wave minimum velocity $6.8 \mathrm{~km} / \mathrm{s}$, minumum crust thicness $5 \mathrm{~km}$, maximum crust thicknes $60 \mathrm{~km}$. Resolution comes from 3DVM model: $12 \mathrm{~km}$ latitude, 12 $\mathrm{km}$ longitude and $6 \mathrm{~km}$ depth. The result is presented in Figure 3.

High depth anomaly in Norht Andean Block, with blue color in the figure, is due to slabcontinental MOHO junction. It is important point out a relevant problem with this model, that is, its excessive discontinuity.

For treatement information about three models de- tailed in this study, specific softwares in Fortran 90 and Matlab should be developed.

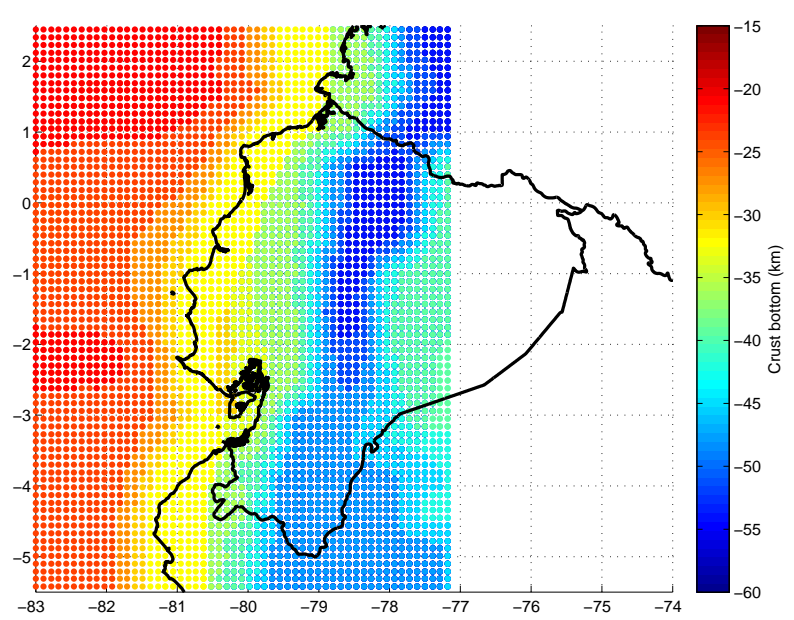

Figure 3. MOHO model obtained from a threedimensional velocity model. Original model covers latitude, and does not extend away from $77^{\circ} \mathrm{W}$, that is the reason for no data. From the coast to the Amazon we can discern the oceanic crust, North Andean block, the Andes Cordillera and Amazon basin.

\section{Results and discussion}

Before trying to select the best of the former presented models it is important to fix a minimum wide geodynamical context in Ecuador (Jaillard et al., 2002).

Under the Pacific Ocean the limit of the Nazca Plate and the mantle is about $10 \mathrm{~km}$ depth. Coastal Lowlands have almost the same MOHO depth but they show volcanic-sedimentary islands and rocks and Cenozoic sediments. The Western Cordillera is formed by accreted oceanic crust and volcanicsedimentary rocks where crust thickness can reach $40 \mathrm{~km}$. The Inter Andean Valley has Cenozoic and Mesozoic sediments, Paleozoic rocks partly metamorphosed, a Precambrian basement and accreted 
oceanic crust with total thickness of $45-50 \mathrm{~km}$. The East Cordillera shows Mesozoic sediments, Paleozoic rocks and the same Precambrian basement when the $\mathrm{MOHO}$ begins to uplift to $40 \mathrm{~km}$. A region of Sub-Andean Hills must be considered with Cenozoic and Mesozoic sediments, Paleozoic rocks and Precambrian basement; here the crust thickness is $35 \mathrm{~km}$. Finally, Amazonian Lowlands have the same composition than the Sub-Andean Hill but here the $\mathrm{MOHO}$ is $30 \mathrm{~km}$ depth only.

With all these geodynamical characteristics in mind, we can see that three models show coincidence in the oceanic and Andes regions. However, in the coastal and Amazonian regions GEMMA model seems to show very small values for the $\mathrm{MOHO}$ depth, than in Gravity and 3D models, that in order, are closer to geodynamical data.

To complete information about $\mathrm{MOHO}$ under Coast and Amazonian Basins, we can use geodynamical characteristics of the North Andean Block and Guiana Shield Realm, two structures welldetermined and accepted today (Cediel et al., 2003; Taboada et al., 2000). This can allow us a comparison between Ecuadorian $\mathrm{MOHO}$ depths and other regions better studied and known like Colombia $\mathrm{MOHO}$, for example, where the North Andean Crust can reach almost $20 \mathrm{~km}$ and Guiana Shield Crust $40 \mathrm{~km}$ (Cediel et al., 2003). Slight differences nevertheless can be seen as Ecuador Crust shows depths from 5 to $15 \mathrm{~km}$ beneath the Borbon Basin, from 15 to $20 \mathrm{~km}$ beneath Manabi Basin and from 20 to $25 \mathrm{~km}$ beneath El Progreso Basin (Cediel et al., 2003).

Regarding Guiana Shield for the Ecuadorian case MOHO depth has more than $30 \mathrm{~km}$ (Cediel et al., 2003). Once again Chambat-Valette and 3DVM models stem MOHO depths lower in coastal and Amazonian Basins while GEMMA does not give correct results in the Progreso Basin. For the Amazonian Basin Chambat-Valette and 3DVM models continue to give more correct depths.

The strategy then to obtain a MOHO model for Ecuador's regions can be summarized as follows:

- 3DVM can only be a reference because it has a lot of discontinuities that are very hard to eliminate in later inversion processes.

- Gravity Chambat-Valette model posits great numeric oscillations in the Andes region. For that reason GEMMA results are taken here.
- Chambat-Valette model are considered under Oceanic Plate, North Andean Block and Guiana Basin.

The result is the MOHO model is showed in Figure 4.

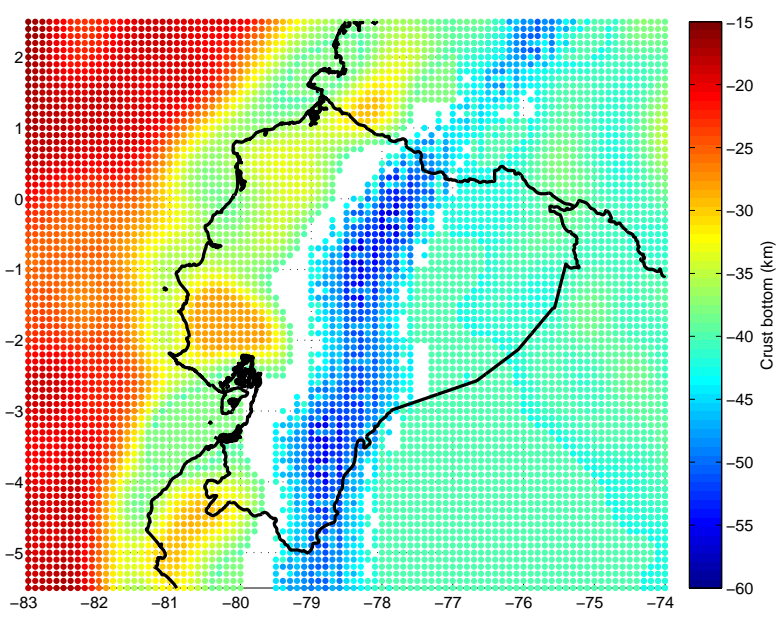

Figure 4. The MOHO model result.

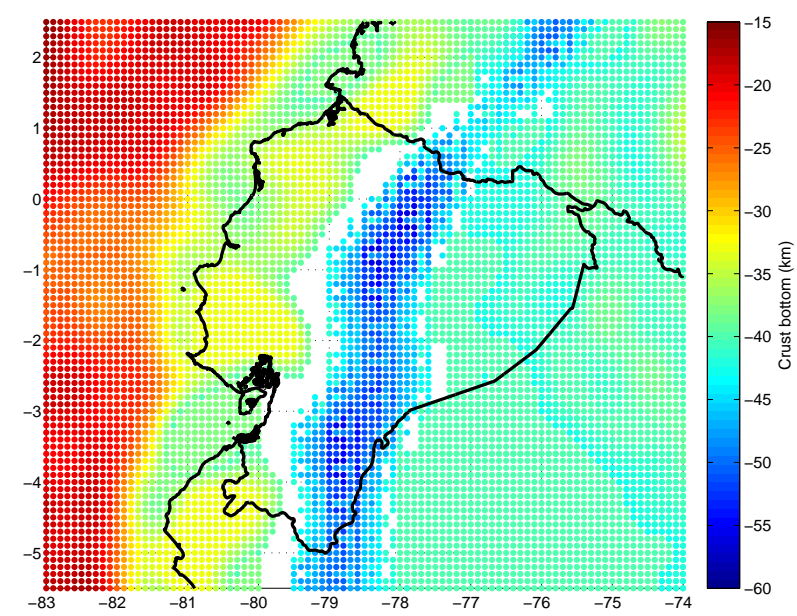

Figure 5. Final MOHO model with anomalies in the North Andean Block corrected to a $-33 \mathrm{~km}$ value.

\section{Conclusion}

A wide knowledge in the geodinamics of Ecuador has guided the final accomplishment of the MOHO model. 
A final correction could be necessary: three $\mathrm{MOHO}$ anomalies in Pacific Coast Ecuadorian Region can be seen in orange color over Figure 5 that represent probable uplifments of $\mathrm{MOHO}$ related to the presence of great sedimentary basins. However, depth values seem to be too high. The correction on these regions can be appreciated in a figure that can be used in forward tomographic inversion processes.

\section{References}

Cediel, F., R. P. Shaw and C. Caceres. 2003. Tectonic assembly of the northern andean block. The Circum-Gulf of Mexico and the Caribbean: Hydrocarbon habitats, basin formation, and plate tectonics: AAPG, 19(5): 815-848.

Chambat, F. 1996. Figure de la Terre : Gravimétrie, régime de contraintes et vibrations propres. Thèse de Doctorat, Université Paris 7.

Cook, F. A., D. White, A. Jones, D. Eaton, J. Hall and R. Clowes. 2010. How the crust meets the mantle: Lithoprobe perspectives on the mohorovicic discontinuity and crust-mantle transition. Can. J. Earth Sci., 47: 315-351.

Eaton, D. 2006. Multi-generic origin of the continental moho: insights from lithoprobe. J. Terra Nova, 18: 34-36.

Font, Y., M. Segovia, S. Vaca and T. Theunissen. 2013. Seismicity patterns along the ecuadorian subduction zone: new constraints from earthquake location in a 3-d a priori velocity model. Geophys, 13.

Jaillard, E., G. Herail, T. Monfret and G. Worner. 2002. Andean geodynamics: main issues and contributions from the 4th isag, gottingen. Tectonophysics, 345: 1-15.

Katsumata, A. and N. Kamaya. 2003. Lowfrequency continuous tremor around the moho discontinuity away from volcanoes in the southwest japan akio. Geophysical Research Letters, 30(1): 1020.

Machetel, P. 2008. Les pulsations de la Terre: Dynamique du Manteau. Vuibert.

Reguzzoni, M. and D. Sampietro. 2012. Moho estimation using goce data: a numerical simulation. International Association of Geodesy Symposia, "Geodesy for Planet Earth", 136: 205-214.

Scholz, C. 2002. The Mechanics of Earthquakes and Faulting. Cambridge University Press.

Shelly, D., G. C. Beroza, S. Ide and S. Nakamula. 2006. Low-frequency earthquakes in shikoku, japan, and their relationship to episodic tremor and slip. Nature, 442.

Taboada, A., L. Rivera, A. Fuenzalida, A. Cisternas, H. Philip, H. Bijwaard, J. Olaya and C. Rivera. 2000. Geodynamicsof the northern andes' subductions and intracontinental deformation. Tectonics, 19(5): 787-813. 